\author{
I.N. Parasidis* ${ }^{*}$ E. Providas \\ University of Thessaly, Larissa, Greece \\ (E-mail: paras@uth.gr,providas@uth.gr)
}

\title{
Factorization method for solving nonlocal boundary value problems in Banach space
}

\begin{abstract}
This article deals with the factorization and solution of nonlocal boundary value problems in a Banach space of the abstract form

$$
B_{1} u=\mathcal{A} u-S \Phi(u)-G \Psi\left(A_{0} u\right)=f, \quad u \in D\left(B_{1}\right),
$$

where $\mathcal{A}, A_{0}$ are linear abstract operators, $S, G$ are vectors of functions, $\Phi, \Psi$ are vectors of linear bounded functionals, and $u, f$ are functions. It is shown that the operator $B_{1}$ under certain conditions can be factorized into a product of two simpler lower order operators as $B_{1}=B B_{0}$. Then the solvability and the unique solution of the equation $B_{1} u=f$ easily follow from the solvability conditions and the unique solutions of the equations $B v=f$ and $B_{0} u=v$. The universal technique proposed here is essentially different from other factorization methods in the respect that it involves decomposition of both the equation and boundary conditions and delivers the solution in closed form. The method is implemented to solve ordinary and partial Fredholm integro-differential equations.
\end{abstract}

Keywords: boundary value problems, nonlocal conditions, factorization, linear operators, integro-differential equations, closed-form solutions.

\section{Introduction}

Let $X$ be a complex Banach space and $X^{*}$ the adjoint space of $X$, i.e., the set of all complex-valued linear bounded functionals $\phi$ on $X$. Let $\mathcal{A}, A_{0}: X \rightarrow X$ be linear operators with boundary conditions incorporated, $\Phi=\operatorname{col}\left(\phi_{1}, \phi_{2}, \ldots, \phi_{m}\right), \Psi=\operatorname{col}\left(\psi_{1}, \psi_{2}, \ldots, \psi_{m}\right)$ vectors of linear bounded functionals $\phi_{i}, \psi_{i}, i=1,2, \ldots, m$, and $S\left(s_{1}, s_{2}, \ldots, s_{m}\right), G=\left(g_{1}, g_{2}, \ldots, g_{m}\right)$ vectors of functions $s_{i}, g_{i} \in X, i=1,2, \ldots, m$. Let the operator $B_{1}: X \rightarrow X$ be defined by

$$
B_{1}=\mathcal{A}-S \Phi-G \Psi\left(A_{0}\right)
$$

and consider the boundary value problem

$$
B_{1} u=\mathcal{A} u-S \Phi(u)-G \Psi\left(A_{0} u\right)=f, \quad u \in D\left(B_{1}\right)
$$

where $f \in X$ is a given forcing function and $u$ is the unknown function.

The primary objective of the paper is to establish factorization conditions under which this problem can be decomposed into two simpler lower order boundary value problems and derive the unique solution in closed form. The second goal is to implement this procedure to solve boundary value problems for ordinary and partial Fredholm integro-differential equations with nonlocal boundary conditions. In this case $B_{1}$ is an integrodifferential operator, $\mathcal{A}$ is a differential operator of order $n$ with nonlocal boundary conditions incorporated, and the functionals $\phi_{i}, \psi_{i}, i=1, \ldots, m$ are integrals with constant limits.

Integro-differential equations model many situations in biology, physics, economics, engineering and applied mathematics. Boundary value problems involving an integro-differential equation and nonlocal boundary conditions are very difficult to solve analytically and therefore very often numerical methods are employed. Factorization methods, where they can be applied, can reduce the problem to simpler lower order problems which can be solved and thus construct the solution of the initial complex problem [1-20].

The novelty of the factorization method presented here differs from other factorization methods in the literature in the respect that it involves decomposition of both the equation and boundary conditions and

\footnotetext{
${ }^{*}$ Corresponding author.

E-mail: paras@uth.gr
} 
delivers the solution in closed form. The technique is new development in Banach spaces and an extension of a procedure used successfully by the authors to solve various other boundary value problems [21-24] and [25-27].

The method is simple to program to any Computer Algebra System.

The rest of the paper is organized as follows. In Section 1 some preliminary results are quoted. In Section 2 the solvability, uniqueness and decomposition conditions are established and the factorization solution method is explicated. In Section 3 two example problems are solved to show the implementation and efficiency of the method.

\section{Preliminaries}

Let $X, Y$ be complex Banach space and $A: X \rightarrow Y$ a linear operator with $D(A)$ and $R(A)$ denoting its domain and range, respectively. We recall that $A$ is said to be injective (or uniquely solvable) if for all $u_{1}, u_{2} \in D(A)$ such that $A u_{1}=A u_{2}$, follows that $u_{1}=u_{2}$; alternatively, $A$ is injective if and only if ker $A=\{0\}$. The operator $A$ is called surjective (or everywhere solvable) if $R(A)=Y$. The operator $A$ is called bijective if $A$ is both injective and surjective. Lastly, $A$ is said to be correct if $A$ is bijective and its inverse $A^{-1}$ is bounded on $Y$. The problem $A u=f$ is called correct if the operator $A$ is correct.

An operator $B_{1}: X \rightarrow X$ is said to be factorable if there exist two operators $B_{0}, B: X \rightarrow X$ such that $B_{1}$ can be written as a product $B_{1}=B B_{0}$. In this case, $B B_{0}$ is a factorization (decomposition) of $B_{1}$.

Throughout the paper, we will use the notation $\Phi(g)$ to denote the $m \times m$ matrix whose $i, j$-th entry $\phi_{i}\left(g_{j}\right)$ is the value of the functional $\phi_{i}$ on element $g_{j}$, where $i, j=1, \ldots, m$. Note that $\Phi(g C)=\Phi(g) C$, where $C$ is a $m \times k$ constant matrix. We will also denote by $\mathbf{c}$ the column vector $\mathbf{c}=\operatorname{col}\left(c_{1}, \ldots, c_{m}\right)$ and by $0_{m}, I_{m}$ the zero and identity $m \times m$ matrices, respectively.

We recall Corollary 3.11 from [25] which will need to prove the theorems below.

Corollary 1. Let $A$ be a correct operator on a Banach space $X$ and the components of the vectors $G=\left(g_{1}, \ldots, g_{m}\right)$ and $F=\operatorname{col}\left(F_{1}, \ldots F_{m}\right)$ are arbitrary elements of $X$ and $X^{*}$, respectively. Then the operator $B: X \rightarrow X$ defined by

$$
B u=A u-G F(A u)=f, \quad D(B)=D(A), \quad f \in X
$$

is correct if and only if

$$
\operatorname{det} L=\operatorname{det}\left[I_{m}-F(G)\right] \neq 0 \text {. }
$$

If $B$ is correct, then the unique solution of (1) for every $f \in X$ is given by

$$
u=B^{-1} f=A^{-1} f+A^{-1} G\left[I_{m}-F(G)\right]^{-1} F(f) .
$$

The following theorem is the generalization of Theorem 1 in [28] and here we prove it without requiring the correctness of the operator $A$ and the linear independence of the components of the functional vector $\Psi=\operatorname{col}\left(\psi_{1}, \ldots, \psi_{m}\right)$.

Theorem 2. Let $X, Y$ and $Z$ be Banach spaces and $A: X \rightarrow Y$ be a linear injective operator with $D(A) \subset Z \subseteq X$. Further let the vector $G=\left(g_{1}, \ldots, g_{m}\right) \in Y^{m}$ and the column vector $\Psi=\operatorname{col}\left(\psi_{1}, \ldots, \psi_{m}\right)$, where $\psi_{1}, \ldots, \psi_{m} \in Z^{*}$. Then:

(i) The operator $B: X \rightarrow Y$ defined by

$$
B u=A u-G \Psi(u)=f, \quad D(B)=D(A), \quad f \in X,
$$

is injective if and only if

$$
\operatorname{det} W=\operatorname{det}\left[I_{m}-\Psi\left(A^{-1} G\right)\right] \neq 0 .
$$

(ii) If $B$ is injective and $A$ is bijective, then $B$ is bijective and for any $f \in Y$, the unique solution of (4) is given by

$$
u=B^{-1} f=A^{-1} f+A^{-1} G W^{-1} \Psi\left(A^{-1} f\right) .
$$

(iii) If $B$ is injective and $A$ is correct, then $B$ is correct.

Proof. (i) The sufficient injectiveness condition of the operator $B$ is proved as in [28].

Now, we prove the converse statement "if the operator $B$ is injective, then $\operatorname{det} W \neq 0$ " or equivalently "if $\operatorname{det} W=0$, then the operator $B$ is not injective". Suppose $\operatorname{det} W=0$. Then there exists a nonzero vector $\mathbf{c}=\operatorname{col}\left(c_{1}, \ldots, c_{m}\right)$ such that $W \mathbf{c}=\mathbf{0}$. Consider the element $u_{0}=A^{-1} G \mathbf{c}$. This element is nonzero, because otherwise we would have

$$
W \mathbf{c}=\left[I_{m}-\Psi\left(A^{-1} G\right)\right] \mathbf{c}=\mathbf{c}-\Psi\left(A^{-1} G \mathbf{c}\right)=\mathbf{c} \neq \mathbf{0},
$$


which is a contradiction. Further,

$$
B u_{0}=A u_{0}-G \Psi\left(u_{0}\right)=G \mathbf{c}-G \Psi\left(A^{-1} G\right) \mathbf{c}=G\left[I_{m}-G \Psi\left(A^{-1} G\right)\right] \mathbf{c}=G W \mathbf{c}=0,
$$

which means that $u_{0} \in \operatorname{ker} B$ and thus $B$ is not injective.

(ii) Let $B$ is injective and $A$ is bijective. Then (5) holds ( $\operatorname{det} W \neq 0$ ) and for any $f \in Y$ from (4) follows that

$$
u=A^{-1} G \Psi(u)+A^{-1} f
$$

and

$$
\begin{gathered}
\Psi(u)=\Psi\left(A^{-1} G\right) \Psi(u)+\Psi\left(A^{-1} f\right), \\
{\left[I_{m}-\Psi\left(A^{-1} G\right)\right] \Psi(u)=\Psi\left(A^{-1} f\right),} \\
\Psi(u)=\left[I_{m}-\Psi\left(A^{-1} G\right)\right]^{-1} \Psi\left(A^{-1} f\right) .
\end{gathered}
$$

Substituting (8) into (7), we obtain the unique solution (6). Since this solution is given for arbitrary $f \in Y$, then $R(B)=Y$, i.e., $B$ is surjective. Hence $B$ is a bijective operator.

(iii) If $B$ is injective and $A$ is correct, then from (6) follows that $B^{-1}$ is bounded since $A^{-1}$ and $\Psi$ are bounded. Hence $B$ is correct.

\section{Main results}

Theorem 3. Let $X$ and $Z_{0}, Z$ be Banach spaces, $Z_{0}, Z \subseteq X$, the vectors $G_{0}=\left(g_{10}, \ldots, g_{m 0}\right), G=\left(g_{1}, \ldots, g_{m}\right)$, $S=\left(s_{1}, \ldots, s_{m}\right) \in X^{m}$, the components of the column vectors $\Phi=\operatorname{col}\left(\phi_{1}, \ldots, \phi_{m}\right)$ and $\Psi=\operatorname{col}\left(\psi_{1}, \ldots, \psi_{m}\right)$ belong to $Z_{0}^{*}$ and $Z^{*}$, respectively, and the operators $B_{0}, B, B_{1}: X \rightarrow X$ be defined by

$$
\begin{gathered}
B_{0} u=A_{0} u-G_{0} \Phi(u)=f, \quad D\left(B_{0}\right)=D\left(A_{0}\right) \subset Z_{0}, \\
B u=A u-G \Psi(u)=f, \quad D(B)=D(A) \subset Z, \\
B_{1} u=A A_{0} u-S \Phi(u)-G \Psi\left(A_{0} u\right)=f, \quad D\left(B_{1}\right)=D\left(A A_{0}\right),
\end{gathered}
$$

where $A_{0}$ and $A$ are linear correct operators on $X$ and $G_{0} \in D(A)^{m}$. Then the following statements are satisfied:

(i) If

$$
S \in R(B)^{m} \quad \text { and } \quad S=B G_{0}=A G_{0}-G \Psi\left(G_{0}\right)
$$

then the operator $B_{1}$ can be factorized as $B_{1}=B B_{0}$.

(ii) If (12) holds, then the operator $B_{1}=B B_{0}$ is correct if and only if the operators $B_{0}$ and $B$ are correct which means that

$$
\operatorname{det} L_{0}=\operatorname{det}\left[I_{m}-\Phi\left(A_{0}^{-1} G_{0}\right)\right] \neq 0 \quad \text { and } \quad \operatorname{det} L=\operatorname{det}\left[I_{m}-\Psi\left(A^{-1} G\right)\right] \neq 0,
$$

and the unique solution of (11) is

$$
\begin{aligned}
u=B_{1}^{-1} f=A_{0}^{-1} A^{-1} f+ & {\left[A_{0}^{-1} A^{-1} G+A_{0}^{-1} G_{0} L_{0}^{-1} \Phi\left(A_{0}^{-1} A^{-1} G\right)\right] L^{-1} \Psi\left(A^{-1} f\right) } \\
& +A_{0}^{-1} G_{0} L_{0}^{-1} \Phi\left(A_{0}^{-1} A^{-1} f\right) .
\end{aligned}
$$

Proof. (i) Taking into account that $G_{0} \in D(A)^{m}$ and (9)-(11) we get

$$
\begin{gathered}
D\left(B B_{0}\right)=\left\{u \in D\left(B_{0}\right): B_{0} u \in D(B)\right\} \\
=\left\{u \in D\left(A_{0}\right): A_{0} u-G_{0} \Phi(u) \in D(A)\right\} \\
=\left\{u \in D\left(A_{0}\right): A_{0} u \in D(A)\right\}=D\left(A A_{0}\right)=D\left(B_{1}\right) .
\end{gathered}
$$

So $D\left(B_{1}\right)=D\left(B B_{0}\right)$. Let $y=B_{0} u$. Then for each $u \in D\left(A A_{0}\right)$ since (10) and (9) we have

$$
\begin{gathered}
B B_{0} u=B y=A y-G \Psi(y) \\
=A\left[A_{0} u-G_{0} \Phi(u)\right]-G \Psi\left(A_{0} u-G_{0} \Phi(u)\right) \\
=A A_{0} u-A G_{0} \Phi(u)-G \Psi\left(A_{0} u\right)+G \Psi\left(G_{0}\right) \Phi(u)
\end{gathered}
$$




$$
\begin{gathered}
=A A_{0} u-\left[A G_{0}-G \Psi\left(G_{0}\right)\right] \Phi(u)-G \Psi\left(A_{0} u\right) \\
=A A_{0} u-B G_{0} \Phi(u)-G \Psi\left(A_{0} u\right),
\end{gathered}
$$

where the relation $B G_{0}=A G_{0}-G \Psi\left(G_{0}\right)$ follows from (10) if instead of $u$ we take $G_{0}$. By comparing (15) with (11) it is easy to verify that $B_{1} u=B B_{0} u$ for each $u \in D\left(A A_{0}\right)$ if a vector $S$ satisfies (12).

(ii) Let the operator $B_{1}$ be defined by (11), where $S=B G_{0}$. Then Equation (11) can be equivalently presented in the matrix form:

$$
B_{1} u=A A_{0} u-\left(B G_{0}, G\right)\left(\begin{array}{c}
\Phi\left(A_{0}^{-1} A^{-1} A A_{0} u\right) \\
\Psi\left(A^{-1} A A_{0} u\right)
\end{array}\right)=f
$$

or

$$
B_{1} u=\mathcal{A} u-\mathcal{G} \mathcal{F}(\mathcal{A} u)=f, \quad D\left(B_{1}\right)=D(\mathcal{A}),
$$

where $\mathcal{A}=A A_{0}, \mathcal{G}=\left(B G_{0}, G\right), \mathcal{F}=\operatorname{col}(\hat{\Phi}, \hat{\Psi})$, and

$$
\mathcal{F}(v)=\left(\begin{array}{c}
\hat{\Phi}(v) \\
\hat{\Psi}(v)
\end{array}\right)=\left(\begin{array}{c}
\Phi\left(A_{0}^{-1} A^{-1} v\right) \\
\Psi\left(A^{-1} v\right)
\end{array}\right) .
$$

Notice that the operator $\mathcal{A}=A A_{0}$ is correct, because of $A$ and $A_{0}$ are correct, and that the vector $\mathcal{F}$ is bounded, since the vector $\hat{\Phi}$ (resp. $\hat{\Psi}$ ) is bounded as a superposition of a bounded functional $\Phi$ (resp. $\Psi$ ) and a bounded operator $A_{0}^{-1} A^{-1}$ (resp. $A^{-1}$ ). Then we apply Corollary 1 . In accordance to $(2),(3)$, the operator $B_{1}$ is correct if and only if

$$
\begin{gathered}
\operatorname{det} L_{1}=\operatorname{det}\left[I_{2 m}-\mathcal{F}(\mathcal{G})\right]=\operatorname{det}\left[\left(\begin{array}{cc}
I_{m} & 0_{m} \\
0_{m} & I_{m}
\end{array}\right)-\left(\begin{array}{cc}
\hat{\Phi}\left(B G_{0}\right) & \hat{\Phi}(G) \\
\hat{\Psi}\left(B G_{0}\right) & \hat{\Psi}(G)
\end{array}\right)\right] \\
=\operatorname{det}\left(\begin{array}{cc}
I_{m}-\hat{\Phi}\left(A G_{0}-G \Psi\left(G_{0}\right)\right) & -\hat{\Phi}(G) \\
-\hat{\Psi}\left(A G_{0}-G \Psi\left(G_{0}\right)\right) & I_{m}-\hat{\Psi}(G)
\end{array}\right) \\
=\operatorname{det}\left(\begin{array}{cc}
I_{m}-\Phi\left(A_{0}^{-1} G_{0}-A_{0}^{-1} A^{-1} G \Psi\left(G_{0}\right)\right) & -\Phi\left(A_{0}^{-1} A^{-1} G\right) \\
-\Psi\left(G_{0}-A^{-1} G \Psi\left(G_{0}\right)\right) & I_{m}-\Psi\left(A^{-1} G\right)
\end{array}\right) \\
=\operatorname{det}\left(\begin{array}{cc}
I_{m}-\Phi\left(A_{0}^{-1} G_{0}\right)+\Phi\left(A_{0}^{-1} A^{-1} G\right) \Psi\left(G_{0}\right) & -\Phi\left(A_{0}^{-1} A^{-1} G\right) \\
-\Psi\left(G_{0}\right)+\Psi\left(A^{-1} G\right) \Psi\left(G_{0}\right) & I_{m}-\Psi\left(A^{-1} G\right)
\end{array}\right) \neq 0 .
\end{gathered}
$$

Multiplying by $\Psi\left(G_{0}\right)$ from the left the second column of the matrix in (16) and then adding to the first column, we get

$$
\begin{gathered}
\operatorname{det} L_{1}=\operatorname{det}\left(\begin{array}{cc}
I_{m}-\Phi\left(A_{0}^{-1} G_{0}\right) & -\Phi\left(A_{0}^{-1} A^{-1} G\right) \\
0_{m} & I_{m}-\Psi\left(A^{-1} G\right)
\end{array}\right) \\
=\operatorname{det}\left[I_{m}-\Phi\left(A_{0}^{-1} G_{0}\right)\right] \operatorname{det}\left[I_{m}-\Psi\left(A^{-1} G\right)\right]=\operatorname{det} L_{0} \operatorname{det} L \neq 0 .
\end{gathered}
$$

So we proved that the operator $B_{1}$ is correct if and only if (13) is fulfilled. From (13), by Theorem 2 , follows that the operators $B$ and $B_{0}$ are correct.

Let now $u \in D\left(A A_{0}\right)$ and $B_{1} u=B B_{0} u=f$. Then, by Theorem 2 (ii), since $B, B_{0}$ are correct operators, we obtain

$$
\begin{gathered}
B_{0} u=B^{-1} f=A^{-1} f+A^{-1} G L^{-1} \Psi\left(A^{-1} f\right), \\
u=B_{0}^{-1}\left(A^{-1} f+A^{-1} G L^{-1} \Psi\left(A^{-1} f\right)\right) .
\end{gathered}
$$

Denote $g=A^{-1} f+A^{-1} G L^{-1} \Psi\left(A^{-1} f\right)$. By using Theorem 2 (ii) again, with $A_{0}, G_{0}, \Phi, L_{0}, g$ in place of $A, G, \Psi, L, f$ respectively, we get

$$
\begin{gathered}
u=B_{0}^{-1} g=A_{0}^{-1} g+A_{0}^{-1} G_{0} L_{0}^{-1} \Phi\left(A_{0}^{-1} g\right)=A_{0}^{-1}\left(A^{-1} f+A^{-1} G L^{-1} \Psi\left(A^{-1} f\right)\right) \\
+A_{0}^{-1} G_{0} L_{0}^{-1} \Phi\left(A_{0}^{-1}\left(A^{-1} f+A^{-1} G L^{-1} \Psi\left(A^{-1} f\right)\right)\right)=A_{0}^{-1} A^{-1} f+A_{0}^{-1} A^{-1} G L^{-1} \Psi\left(A^{-1} f\right) \\
+A_{0}^{-1} G_{0} L_{0}^{-1}\left[\Phi\left(A_{0}^{-1} A^{-1} f\right)+\Phi\left(A_{0}^{-1} A^{-1} G\right) L^{-1} \Psi\left(A^{-1} f\right)\right],
\end{gathered}
$$

which implies (14). The theorem is proved.

The next theorem is useful for applications and is proved by using Theorem 3 . 
Theorem 4. Let the spaces $X, Z_{0}, Z$, the vectors $S, G, \Phi, \Psi$ be defined as in Theorem 3 and the operator $B_{1}: X \rightarrow X$ by

$$
B_{1} u=\mathcal{A} u-S \Phi(u)-G \Psi\left(A_{0} u\right)=f, \quad u \in D\left(B_{1}\right),
$$

where $A_{0}$ is a correct $m$-order differential operator with $D\left(A_{0}\right) \subset Z_{0}$ and $\mathcal{A}$ is a $n$-order differential operator, $m<n$. Then the next statements are fulfilled:

(i) If there exists an $n-m$ order differential bijective operator $A: X \rightarrow X$ such that

$$
\begin{gathered}
\mathcal{A}=A A_{0}, \quad D\left(B_{1}\right)=D\left(A A_{0}\right), \quad D(A) \subset Z \subseteq X, \\
\operatorname{det} L=\operatorname{det}\left[I_{m}-\Psi\left(A^{-1} G\right)\right] \neq 0,
\end{gathered}
$$

then the operator $B_{1}$ is factorized as $B_{1}=B B_{0}$, where $B_{0}, B$ are defined by (9), (10),

$$
G_{0}=A^{-1} S+A^{-1} G L^{-1} \Psi\left(A^{-1} S\right)
$$

the operator $A$ and vectors $G, \Psi$ are determined from (18) and (17), respectively, and the operator $A_{0}$ and a vector $\Phi$ from (17).

(ii) If in addition to (i) $A$ is correct, then the operator $B_{1}=B B_{0}$ is correct if and only if

$$
\operatorname{det} L_{0}=\operatorname{det}\left[I_{m}-\Phi\left(A_{0}^{-1} G_{0}\right)\right] \neq 0
$$

and the unique solution of (17), (18) is given by

$$
u=B_{0}^{-1} B^{-1} f=B_{0}^{-1} v=A_{0}^{-1} v+A_{0}^{-1} G_{0} L_{0}^{-1} \Phi\left(A_{0}^{-1} v\right),
$$

where

$$
v=A^{-1} f+A^{-1} G L^{-1} \Psi\left(A^{-1} f\right) .
$$

Proof. (i) Suppose that there exist the operators $A, B, B_{0}$, defined in (i). Acting by the operator $B$ on the vector $G_{0}$, defined by $(20)$, we get.

$$
\begin{gathered}
B G_{0}=A G_{0}-G \Psi\left(G_{0}\right) \\
=A\left(A^{-1} S+A^{-1} G L^{-1} \Psi\left(A^{-1} S\right)\right)-G \Psi\left(A^{-1} S+A^{-1} G L^{-1} \Psi\left(A^{-1} S\right)\right) \\
=S+G L^{-1} \Psi\left(A^{-1} S\right)-G \Psi\left(A^{-1} S\right)-G \Psi\left(A^{-1} G\right) L^{-1} \Psi\left(A^{-1} S\right) \\
=S+G\left[I_{m}-\Psi\left(A^{-1} G\right)\right] L^{-1} \Psi\left(A^{-1} S\right)-G \Psi\left(A^{-1} S\right)=S .
\end{gathered}
$$

So $B G_{0}=S$. From (17) for $\mathcal{A}=A A_{0}$ and $B G_{0}=S$ we get

$$
B_{1} u=A A_{0} u-B G_{0} \Phi(u)-G \Psi\left(A_{0} u\right)=f, \quad u \in D\left(A A_{0}\right) .
$$

Denote $y=A_{0} u$. Then from (24) for any $u \in D\left(A A_{0}\right)$ follows that

$$
B_{1} u=A y-G \Psi(y)-B G_{0} \Phi(u)=B y-B G_{0} \Phi(u)=B\left(A_{0} u-G_{0} \Phi(u)\right)=B B_{0} u .
$$

In Theorem 3 (i) we proved that $D\left(B B_{0}\right)=D\left(A A_{0}\right)=D\left(B_{1}\right)$. Consequently, $B_{1}$ is factorized in $B_{1}=B B_{0}$.

(ii) Let $A$ be a correct operator. Then by Theorem 2, since (19), (21), the operators $B, B_{0}$ are correct too. Remind that for $G_{0}$, defined by (20), we proved in (i) that $B G_{0}=S$. Then by Theorem 3 (i), (iii), we have the factorization $B_{1}=B B_{0}$ and $B_{1}$ is correct if and only if $\operatorname{det} L \neq 0$ and $\operatorname{det} L_{0} \neq 0$. But by assumption $\operatorname{det} L \neq 0$. Thus $B_{1}$ is correct if and only if (21) holds. Let $B B_{0} u=f$ for any $f \in X$. Then because of the operators $B, B_{0}$ are correct, we obtain

$$
B_{0} u=B^{-1} f=A^{-1} f+A^{-1} G L^{-1} \Psi\left(A^{-1} f\right) .
$$

From the above, denoting $v=A^{-1} f+A^{-1} G L^{-1} \Psi\left(A^{-1} f\right)$, follows that

$$
B_{0} u=v, \quad u=B_{0}^{-1} v=A_{0}^{-1} v+A_{0}^{-1} G_{0} L_{0}^{-1} \Phi\left(A_{0}^{-1} v\right),
$$

which give (23) and (22). So the theorem is proved.

Remark 5. Usually in applications $X$ is the space $C[a, b]$ or $L_{p}(a, b), p=1,2, \ldots$, and $Z_{0}, Z$ are the spaces $C^{k}[a, b]$ or $W_{p}^{k}(a, b), k=1, \ldots, n$, respectively. Problem (17) can be solved by factorization method if it is possible to determine from (17) the vectors $S, G, \Phi, \Psi$ and the operators $A_{0}, A$ such that

$$
\mathcal{A}=A A_{0}, \quad D\left(B_{1}\right)=D\left(A A_{0}\right), \quad D(A) \subset Z, \quad D\left(A_{0}\right) \subset Z_{0}, \quad \operatorname{det} L \neq 0, \quad \operatorname{det} L_{0} \neq 0 .
$$

If the above conditions are fulfilled, then a unique solution to (17) can be found by (22), (23), where $G_{0}$ is given by $(20)$. 


\section{Illustrative Examples}

To explain the implementation of the factorization method and to show its efficiency, we solve two example problems.

Example 1. Let us find the solution of the nonlocal boundary value problem

$$
\begin{gathered}
u^{\prime \prime}(t)-(t+1) \int_{0}^{1}(t-1) u(t) d t-t^{2} \int_{0}^{1} t^{3} u^{\prime}(t) d t=2-3 t, \quad 0<t<1 \\
u(0)+u(1)=0, \quad u^{\prime}(0)-4 u^{\prime}(1)=0 .
\end{gathered}
$$

The operator $B_{1}: C[0,1] \rightarrow C[0,1]$ corresponding to the problem is correct. The unique solution to problem (25) is given by the formula

$$
u(t)=-\frac{5\left(1204 t^{4}+402256 t^{3}-811850 t^{2}+549488 t-70549\right)}{4037236} .
$$

Proof. First we need to find the operators $A, A_{0}$ and check the condition $D\left(B_{1}\right)=D\left(A A_{0}\right)$. If we compare equation (25) with Problem (17), (18), it is natural to take $X=C[0,1], m=1, I_{m}=1$,

$$
\begin{gathered}
\mathcal{A} u=A A_{0} u=u^{\prime \prime}(t), \\
D\left(B_{1}\right)=\left\{u(t) \in C^{2}[0,1]: u(0)+u(1)=0, \quad u^{\prime}(0)-4 u^{\prime}(1)=0\right\}, \\
A_{0} u(t)=u^{\prime}(t), \quad D\left(A_{0}\right)=\left\{u(t) \in C^{1}[0,1]: u(0)=-u(1)\right\} \\
\Phi(u)=\int_{0}^{1}(t-1) u(t) d t, \quad \Psi\left(A_{0} u\right)=\int_{0}^{1} t^{3} u^{\prime}(t) d t
\end{gathered}
$$

$S=t+1, G=t^{2}$. Let us denote $A_{0} u(t)=u^{\prime}(t)=y(t)=y$. Then from (27) we have $y \in D(A)$, $A A_{0} u=\left(u^{\prime}(t)\right)^{\prime}=y^{\prime}(t)=A y(t), y(0)-4 y(1)=0$. So we proved that

$$
A y=y^{\prime}(t), \quad D(A)=\left\{y(t) \in C^{1}[0,1]: y(0)-4 y(1)=0\right\} .
$$

Further by definition we find

$$
\begin{gathered}
D\left(A A_{0}\right)=\left\{u(t) \in D\left(A_{0}\right): A_{0} u(t) \in D(A)\right\} \\
=\left\{u(t) \in C^{1}[0,1]: u(0)=-u(1), u^{\prime}(t) \in C^{1}[0,1], u^{\prime}(0)-4 u^{\prime}(1)=0\right\} \\
=\left\{u(t) \in C^{2}[0,1]: u(0)+u(1)=0, \quad u^{\prime}(0)-4 u^{\prime}(1)=0\right\}=D\left(B_{1}\right) .
\end{gathered}
$$

So $D\left(B_{1}\right)=D\left(A A_{0}\right)$. It is easy to verify that the operators $A, A_{0}$ are correct on $C[0,1]$ and that for every $f(t) \in C[0,1]$ the following formulae hold true

$$
\begin{aligned}
& A^{-1} f(t)=\int_{0}^{t} f(x) d x-\frac{4}{3} \int_{0}^{1} f(x) d x \\
& A_{0}^{-1} f(t)=\int_{0}^{t} f(x) d x-\frac{1}{2} \int_{0}^{1} f(x) d x .
\end{aligned}
$$

From (28) we have

$$
\Phi(f)=\int_{0}^{1}(x-1) f(x) d x, \quad \Psi(f)=\int_{0}^{1} x^{3} f(x) d x .
$$

Then $|\Phi(f)| \leq \frac{1}{2}|| f(x)\left\|_{C}, \quad|\Psi(f)| \leq \frac{1}{4}|| f(x)\right\|_{C}$, that is $\Phi, \Psi \in C^{*}[0,1]$ and $Z_{0}=Z=C[0,1]$. Using (29), (31) and (19), we obtain

$$
\begin{gathered}
A^{-1} G=\int_{0}^{t} x^{2} d x-\frac{4}{3} \int_{0}^{1} x^{2} d x=\frac{t^{3}}{3}-\frac{4}{9} \\
\Psi\left(A^{-1} G\right)=\int_{0}^{1} x^{3}\left(\frac{x^{3}}{3}-\frac{4}{9}\right) d x=-\frac{4}{63}, \\
\operatorname{det} L=\operatorname{det}\left[I_{m}-\Psi\left(A^{-1} G\right)\right]=1+4 / 63=67 / 63, \quad L^{-1}=63 / 67 .
\end{gathered}
$$


So (19) is fulfilled. Further using (20), (23), (29), (31) for $S=t+1, G=t^{2}$ and $f(t)=2-3 t$ we find

$$
\begin{gathered}
A^{-1} f=-\frac{3 t^{2}}{2}+2 t-\frac{2}{3}, \quad \Psi\left(A^{-1} f\right)=-\frac{1}{60}, \\
v=A^{-1} f+A^{-1} G L^{-1} \Psi\left(A^{-1} f\right)=-\frac{7 t^{3}+2010 t^{2}-2680 t+884}{1340}, \\
A^{-1} S=\int_{0}^{t}(x+1) d x-\frac{4}{3} \int_{0}^{1}(x+1) d x=\frac{t^{2}}{2}+t-2, \\
\Psi\left(A^{-1} S\right)=\int_{0}^{1} x^{3}\left(\frac{x^{2}}{2}+x-2\right) d x=-\frac{13}{63}, \\
G_{0}=A^{-1} S+A^{-1} G L^{-1} \Psi\left(A^{-1} S\right)=-\frac{273 t^{3}-2010 t^{2}-4020 t+7676}{4020} .
\end{gathered}
$$

Taking into account (30), (31), we obtain

$$
A_{0}^{-1} G_{0}=-\frac{546 t^{4}-5360 t^{3}-16080 t^{2}+61408 t-20257}{32160}, \quad \Phi\left(A_{0}^{-1} G_{0}\right)=-\frac{44509}{964800} .
$$

Since

$$
\operatorname{det} L_{0}=\operatorname{det}\left[I_{m}-\Phi\left(A_{0}^{-1} G_{0}\right)\right]=\frac{1009309}{964800} \neq 0, \quad \text { then } \quad L_{0}^{-1}=\frac{964800}{1009309},
$$

and by Theorem 4 (ii), Problem (25) is correct. By (30)-(32) we calculate

$$
A_{0}^{-1} v=-\frac{14 t^{4}+5360 t^{3}-10720 t^{2}+7072 t-863}{10720}, \quad \Phi\left(A_{0}^{-1} v\right)=\frac{1223}{107200} .
$$

Substituting these values into (22), i.e.,

$$
u=A_{0}^{-1} v+A_{0}^{-1} G_{0} L_{0}^{-1} \Phi\left(A_{0}^{-1} v\right),
$$

we obtain the unique solution to (25), which is given by (26).

Example 2. Let $\bar{\Pi}=\left\{(t, s) \in \mathbb{R}^{2}: 0 \leq t, s \leq 1\right\}, u=u(t, s), u_{t}^{\prime}, u_{t s}^{\prime \prime} \in C(\bar{\Pi})$. The operator $B_{1}: C(\bar{\Pi}) \rightarrow C(\bar{\Pi})$ corresponding to the problem:

$$
\begin{gathered}
u_{t s}^{\prime \prime}(t, s)-(2 t-s) \int_{0}^{1} \int_{0}^{1} u(t, s) d t d s-(t+s) \int_{0}^{1} \int_{0}^{1} t s u_{t}^{\prime}(t, s) d t d s \\
=-\frac{213 s+149 t-600}{220}, \\
u(0, s)=s \int_{0}^{1} \int_{0}^{1} t^{2} u(t, s) d t d s, \\
u_{t}^{\prime}(t, 0)=(2 t-1) \int_{0}^{1} \int_{0}^{1}(s+3) u_{t}^{\prime}(t, s) d t d s
\end{gathered}
$$

is correct. The unique solution to Problem (33) is given by the formula

$$
u(t, s)=\frac{6 s(25 t+1)+275 t(t-1)}{55} .
$$

Proof. First we need to find the operators $A, A_{0}$ and check the condition $D\left(B_{1}\right)=D\left(A A_{0}\right)$. If we compare (33) with Problem (17), (18), it is natural to take $X=C(\bar{\Pi}), m=1, I_{m}=1$,

$$
\begin{gathered}
A A_{0} x=u_{t s}^{\prime \prime}(t, s), \\
D\left(B_{1}\right)=\left\{u(t, s) \in C(\bar{\Pi}), u_{t}^{\prime}, u_{t s}^{\prime \prime} \in C(\bar{\Pi}), \quad u(0, s)=s \int_{0}^{1} \int_{0}^{1} t^{2} u(t, s) d t d s,\right.
\end{gathered}
$$




$$
\begin{gathered}
\left.u_{t}^{\prime}(t, 0)=(2 t-1) \int_{0}^{1} \int_{0}^{1}(s+3) u_{t}^{\prime}(t, s) d t d s\right\} \\
A_{0} u(t, s)=u_{t}^{\prime}(t, s), \\
D\left(A_{0}\right)=\left\{u(t, s) \in C(\bar{\Pi}): u_{t}^{\prime}(t, s) \in C(\bar{\Pi}), \quad u(0, s)=s \int_{0}^{1} \int_{0}^{1} t^{2} u(t, s) d t d s\right\}, \\
\Phi(u)=\int_{0}^{1} \int_{0}^{1} u(t, s) d t d s, \quad \Psi\left(A_{0} u\right)=\int_{0}^{1} \int_{0}^{1} t s u_{t}^{\prime}(t, s) d t d s,
\end{gathered}
$$

$S=2 t-s, G=t+s, f=-(213 s+149 t-600) / 220$. In $(37)$, denote $A_{0} u(t, s)=u_{t}^{\prime}(t, s)=y(t, s)=y$. Then from $(35),(36)$ we have $y \in D(A), A A_{0} u=\left(u_{t}^{\prime}(t, s)\right)_{s}^{\prime}=y_{s}^{\prime}(t, s)=A y(t, s)$ and $y(t, 0)=(2 t-1) \int_{0}^{1} \int_{0}^{1}(s+3) y(t, s) d t d s$. So we proved that

$$
A y=y_{s}^{\prime}(t, s), \quad D(A)=\left\{y(t, s) \in C(\bar{\Pi}): y_{s}^{\prime} \in C(\bar{\Pi}), y(t, 0)=(2 t-1) \int_{0}^{1} \int_{0}^{1}(s+3) y(t, s) d t d s\right\} .
$$

Then by definition

$$
\begin{gathered}
D\left(A A_{0}\right)=\left\{u(t, s) \in D\left(A_{0}\right): A_{0} u(t, s) \in D(A)\right\} \\
=\left\{u(t, s) \in C(\bar{\Pi}): u_{t}^{\prime} \in C(\bar{\Pi}), \quad u(0, s)=s \int_{0}^{1} \int_{0}^{1} t^{2} u(t, s) d t d s\right. \\
\left.u_{t}^{\prime}(t, 0)=(2 t-1) \int_{0}^{1} \int_{0}^{1}(s+3) u_{t}^{\prime}(t, s) d t d s, \quad u_{t s}^{\prime \prime}(t, s) \in C(\bar{\Pi})\right\} \\
=\left\{u(t, s) \in C(\bar{\Pi}), u_{t}^{\prime}, u_{t s}^{\prime \prime} \in C(\bar{\Pi}), \quad u(0, s)=s \int_{0}^{1} \int_{0}^{1} t^{2} u(t, s) d t d s,\right. \\
\left.u_{t}^{\prime}(t, 0)=(2 t-1) \int_{0}^{1} \int_{0}^{1}(s+3) u_{t}^{\prime}(t, s) d t d s\right\}=D\left(B_{1}\right) .
\end{gathered}
$$

Thus $D\left(B_{1}\right)=D\left(A A_{0}\right)$. It is easy to verify that the operators $A, A_{0}$ are correct on $C(\bar{\Pi})$ and for every $f(t, s) \in C(\bar{\Pi})$ hold true

$$
\begin{gathered}
A^{-1} f(t, s)=\int_{0}^{s} f(t, x) d x+(2 t-1) \int_{0}^{1} \int_{0}^{1} \int_{0}^{s}(s+3) f(t, x) d x d t d s \\
A_{0}^{-1} f(t, s)=\int_{0}^{t} f(z, s) d z+\frac{6 s}{5} \int_{0}^{1} \int_{0}^{1} \int_{0}^{t} t^{2} f(z, s) d z d t d s
\end{gathered}
$$

From (38) we get

$$
\Phi(f)=\int_{0}^{1} \int_{0}^{1} f(t, s) d t d s, \quad \Psi(f)=\int_{0}^{1} \int_{0}^{1} t s f(t, s) d t d s .
$$

Then $\Phi, \Psi \in C^{*}(\bar{\Pi})$ and $Z_{0}=Z=C(\bar{\Pi})$. Using (39), (41) and (19) we obtain

$$
A^{-1} G=\frac{s^{2}}{2}+s t+\frac{37(2 t-1)}{24}, \quad \Psi\left(A^{-1} G\right)=\frac{29}{96}, \quad L=1-\Psi\left(A^{-1} G\right)=67 / 96, \quad L^{-1}=96 / 67 .
$$

So (19) is fulfilled. Further, using (39), (41), (23), (20) for $S=2 t-s, G=t+s$ and $f(t)=-(213 s+149 t-$ $-600) / 220$ we find

$$
\begin{gathered}
A^{-1} f=-\frac{2556 s^{2}+24 s(149 t-600)-19927(2 t-1)}{5280}, \quad \Psi\left(A^{-1} f\right)=\frac{2675}{4224}, \\
v=A^{-1} f+A^{-1} G L^{-1} \Psi\left(A^{-1} f\right)=-\frac{336 s^{2}-6 s(424 t+5025)-57187(2 t-1)}{11055}, \\
A^{-1} S=-\frac{s^{2}}{2}+2 s t+\frac{29(2 t-1)}{24}, \quad \Psi\left(A^{-1} S\right)=\frac{25}{96},
\end{gathered}
$$




$$
G_{0}=A^{-1} S+A^{-1} G L^{-1} \Psi\left(A^{-1} S\right)=-\frac{42 s^{2}-318 s t-239(2 t-1)}{134} .
$$

Taking into account (40), (41) we obtain

$$
A_{0}^{-1} G_{0}=-\frac{2100 s^{2} t-3 s\left(2650 t^{2}+9\right)-11950 t(t-1)}{6700}, \quad \Phi\left(A_{0}^{-1} G_{0}\right)=-\frac{6019}{40200} .
$$

Since

$$
\operatorname{det} L_{0}=\operatorname{det}\left[I_{m}-\Phi\left(A_{0}^{-1} G_{0}\right)\right]=\frac{46219}{40200} \neq 0,
$$

then $L_{0}^{-1}=\frac{40200}{46219}$, and hence by Theorem 4 (ii), problem (33) is correct. By (40)-(42) we calculate

$$
\begin{gathered}
A_{0}^{-1} v=-\frac{8400 s^{2} t-6 s\left(5300 t^{2}+125625 t+5043\right)-1429675 t(t-1)}{276375}, \\
\Phi\left(A_{0}^{-1} v\right)=-\frac{92438}{829125} .
\end{gathered}
$$

Substituting the above values into (22), we obtain, by Theorem 4 (ii), the unique solution of (33)

$$
u=A_{0}^{-1} v+A_{0}^{-1} G_{0} L_{0}^{-1} \Phi\left(A_{0}^{-1} v\right)=\frac{6 s(25 t+1)+275 t(t-1)}{55},
$$

which is (34).

\section{References}

1 Adomian, G. (1994). Solving frontier problems of physics: The decomposition method. Kluwer Academic Publishers, Boston.

2 Barkovsky, L.M. (2002). Factorization of integro-differential equations of the acoustics of dispersive viscoelastic anisotropic media and the tensor integral operators of wake packet velocities. Acoustical Physics 48, 128-132.

3 Bloom, F. (1981). Ill posed Problems for Integrodifferential equations in mechanics and electromagnetic theory. SIAM. https://doi.org/10.1137/1.9781611970890.

4 Caruntu, D.I. (1996). Relied studies on factorization of the differential operator in the case of bending vibration of a class of beams with variable cross-section. Revue Roumaine des Sci. Tech. Serie de Micanique Appl., 41(5-6), 389-397.

5 Dong, S.H. (2007). Factorization method in quantum mechanics. Fund. Theories Phys. 150. Springer, Dordrecht.

6 Geiser, J. (2009). Decomposition methods for differential equations: theory and applications. CRC Press, Taylor and Francis Group.

7 Hirsa, A., \& Neftci, S.N. (2013). An introduction to the mathematics of financial derivatives. Academic Press, Cambridge. doi.org/10.1016/C2010-0-64929-7

8 Kelesoglu, O. (2014). The solution of fourth order boundary value problem arising out of the beam-column theory using adomian decomposition method. Mathematical Problems in Engineering, 2014 , ID 649471. https://doi.org/10.1155/2014/649471

9 Kil'chevski, N.A. (1959). Integro-differential and integral equations of equilibrium of thin elastic shells. PMM, 23(1), 124-133.

10 Medlock, J., \& Kot, M. (2003). Spreading disease: integro-differential equations old and new. Math. Biosci. 184, 201-222. https://doi.org/10.1016/S0025-5564(03)00041-5

11 Nyashin, Y., Lokhov, V., \& Ziegler, F. (2005). Decomposition method in linear elastic problems with eigenstrain. Z. Angew. Math. Mech., 85, 557-570.

12 Araghi, M., \& Behzadi, S. (2009). Solving nonlinear Volterra-Fredholm integro-differential equations using the modified Adomian decomposition method. Comput. Methods Appl. Math., 9(4), 321-331.

13 Babolian, E., Biazar, J, \& Vahidi, A.R. (2004). The decomposition method applied to systems of Fredholm integral equations of the second kind. Appl. Math. Comput., 148, 443-452. 
14 Baskonus, H.M., Bulut, H., \& Pandir, Y. (2014). The natural transform decomposition method for linear and nonlinear partial differential equations. Mathematics in Engineering, Science and Aerospace, 5(1), $111-126$.

15 Hamoud, A.A., \& Ghadle, K.P. (2017). The reliable modified of Laplace Adomian decomposition method to solve nonlinear interval Volterra-Fredholm integral equations. Korean J. Math., 25(3), 323-334.

16 Khachatryan, A.K., \& Khachatryan K.A. (2008). Factorization of a convolution-type integrodifferential equation on the positive half line. Ukrains'kyi Matematychnyi Zhurnal, 60(11), 1555-1567. http://umj.imath.kiev.ua/index.php/umj/article/view/3269

17 Al-Khaled, K., \& Allan, F. (2005). Decomposition method for solving nonlinear integro-differential equations. J. Appl. Math. Computing, 19(1-2), 415-425.

18 Mittal, R. \& Nigam, R. (2008). Solution of fractional integro-differential equations by Adomian decomposition method. Int. J. Appl. Math. Mech., 4(2), 87-94.

19 Moumouni, S., Soumanou, V.M.S., Massou, S., Essoun, A.L., \& Tchoffo, M. (2016). Generalization and resolution of the homogeneous reaction-diffusion equations by the method of factorization of ordinary differential operators. Advances in Differential Equations and Control Processes, 17(4), 265-283. http:// dx.doi.org/10.17654/DE017040265

20 Yang, C., Hou, J. (2013). Numerical solution of integro-differential equations of fractional order by Laplace decomposition method. Wseas Trans. Math., 12(12), 1173-1183.

21 Parasidis, I.N., Providas E., \& Tsekrekos, P.C. (2012). Factorization of linear operators and some eigenvalue problems of special operators. Vestn. Bashkir. Univ., 17(2), 830-839.

22 Parasidis, I.N. (2019). Extension and decomposition method for differential and integro-differential equations. Eurasian Mathematical Journal, 10(3), 48-67.

23 Providas, E. (2021). Operator factorization and solution of second-order nonlinear difference equations with variable coefficients and multipoint constraints. In T.M. Rassias, P.M. Pardalos (Eds.), Nonlinear Analysis and Global Optimization (pp. 427-443 ). Springer Optimization and Its Applications, vol. 167. Springer, Cham. https://doi.org/10.1007/978-3-030-61732-5

24 Providas, E. (2021). Factorization and solution of linear and nonlinear second order differential equations with variable coefficients and mixed conditions. In T.M. Rassias (Ed.), Nonlinear Analysis, Differential Equations and Applications. Springer Optimization and Its Applications, vol. 173. Springer, Cham (2021). https://doi.org/10.1007/978-3-030-72563-1

25 Parasidis, I.N., \& Tsekrekos, P.C. (2010) Some quadratic correct extensions of minimal operators in Banach space. Operators and Matrices, 4 (2), 225-243. dx.doi.org/10.7153/oam-04-11

26 Vassiliev, N.N., Parasidis, I.N., \& Providas, E. (2019). Exact solution method for Fredholm integrodifferential equations with multipoint and integral boundary conditions. Part 2. Decomposition-extension method for squared operators. Information and Control Systems, 2, 2-9.

https://doi.org/10.31799/1684-8853-2019-2-2-9

27 Parasidis, I.N., Providas, E., \& Zaoutsos, S. (2020). On the solution of boundary value problems for ordinary differential equations of order $\mathrm{n}$ and $2 \mathrm{n}$ with general boundary conditions. In N. Daras, T. Rassias (Eds.), Computational Mathematics and Variational Analysis (pp. 299-314). Springer Optimization and Its Applications, vol 159. Springer, Cham. https://doi.org/10.1007/978-3-030-44625-3

28 Parasidis, I.N., \& Providas, E. (2016). Extension operator method for the exact solution of integrodifferential equations. In P. Pardalos, T. Rassias (Eds). Contributions in Mathematics and Engineering (pp. 473-496). Springer, Cham. https://doi.org/10.1007/978-3-319-31317-7 
И.Н. Парасидис, Е. Провидас

Фессалия университеті, Лариса, Грещия

\title{
Банах кеңістігінде локальді емес шекаралық есептерді шешуге арналған факторизация әдісі
}

Мақала банах кеңістігінде абстрактілі операторлары бар

$$
B_{1} u=\mathcal{A} u-S \Phi(u)-G \Psi\left(A_{0} u\right)=f, \quad u \in D\left(B_{1}\right),
$$

түріндегі локалды емес шектік есептерді факторизациялау және шешуге арналған, мұндағы $\mathcal{A}, A_{0}$ сызықтық дерексіз операторлар, $S, G$ функция векторлары, $\Phi, \Phi$ сызықтық шектеулі функционалды векторлар және $u, f$ функциялар. $B_{1}$ операторы белгілі бір жағдайларда $B_{1}=B b_{0}$ кіші екі қарапайым оператордың көбейтіндісіне факторлануы мүмкін екендігі көрсетілген. Содан кейін $B_{1} u=f$ теңдеуінің шешімі мен жалғыз шешімі $B v=f$ және $b_{0} u=v$ теңдеулер шешімдерінің шешімділігі мен бірегейлігі шарттарынан оңай туындайды. Ұсынылған әмбебап әдіс басқа факторизация әдістерінен айтарлықтай ерекшеленеді, өйткені оған теңдеу мен шекаралық шарттардың факторизациясы кіреді және шешімді жабық түрде ұсынады. Бұл әдіс Фредгольмның қарапайым және жартылай интегродифференциалдық теңдеулерін шешуге арналған.

Kiлm сөздер: шекаралық есептер, жергілікті емес жағдайлар, факторизация, сызықтық операторлар, интегро-дифференциалдық теңдеулер, жабық түрдегі шешімдер.

\author{
И.Н. Парасидис, Е. Провидас \\ Университет Фессалии, Лариса, Греция
}

\section{Метод факторизации для решения нелокальных краевых задач в банаховом пространстве}

Статья посвящена факторизации и решению нелокальных краевых задач с операторами абстрактного вида

$$
B_{1} u=\mathcal{A} u-S \Phi(u)-G \Psi\left(A_{0} u\right)=f, \quad u \in D\left(B_{1}\right),
$$

в банаховом пространстве, где $\mathcal{A}, A_{0}$ - линейные абстрактные операторы; $S, G$ - векторы функций; $\Phi, \Psi$ - векторы линейных ограниченных функционалов; а $u, f$ - функции. Показано, что оператор $B_{1}$ при определенных условиях может быть факторизован в произведение двух более простых операторов меньшего порядка $B_{1}=B B_{0}$. Тогда разрешимость и единственное решение уравнения $B_{1} u=f$ легко следует из условий разрешимости и единственности решений уравнений $B v=f$ и $B_{0} u=v$. Предлагаемый универсальный метод существенно отличается от других методов факторизации, поскольку он включает факторизацию уравнения и граничных условий и предоставляет решение в замкнутой форме. Метод разработан для решения обыкновенных и частных интегро-дифференциальных уравнений Фредгольма.

Ключевые слова: краевые задачи, нелокальные условия, факторизация, линейные операторы, интегродифференциальные уравнения, решения в замкнутой форме. 